\title{
TEMPLATE PREPARATION FOR RAPID PCR IN COLLETOTRICHUM LINDEMUTHIANUM
}

\author{
M. Gabriela Roca*; Lisete C. Davide ${ }^{1}$; Alan E. Wheals ${ }^{2}$ \\ ${ }^{1}$ Departamento de Biologia, Universidade Federal de Lavras, Lavras, MG, Brasil; ${ }^{2}$ Department of Biology and Biochemistry, \\ University of Bath, United Kingdom.
}

Submitted: January 24, 2002; Returned to authors for corrections: April 18, 2002; Approved: October 16, 2002

\section{SHORT COMMUNICATION}

\begin{abstract}
Isolation of DNA for PCR is time-consuming and involves many reagents. The aim of this work was to optimise a rapid and easy PCR methodology without previous DNA isolation. Different strains of the phytopathogenic fungus Colletotrichum lindemuthianum were used. Protoplasts were generated using lytic enzymes under high incubation temperatures using different methodologies to obtain the template. A rapid (10 minute) methodology was successful for smaller amplicons ( $<750 \mathrm{bp})$.
\end{abstract}

Key words: anthracnose, hygromycin resistance, internal transcribed spacer, rapid screening, PCR methodology

The fungus Colletotrichum lindemuthianum (Sacc. \& Magn.) Scribner is the causative agent of anthracnosis, one of the most important diseases of the common bean in Brazil (14). Due to its economic damage and widespread abundance, this fungus has been subjected to intensive study with the aim of developing both new varieties of beans that are genetically resistant to $C$. lindemuthianum as well as understanding the genetic basis of pathogenicity.

PCR (Polymerase Chain Reaction), that allows the characterization of the DNA of individual or populations, is among methodologies that have been applied to the study of genetic variability of fungi. The most time-consuming requirement of this process is usually DNA extraction and this can hinder its effective deployment when either a large number of samples need to be analysed or when there is only a small amount of material for DNA extraction. Some DNA extraction protocols for fungi use toxic chemicals (17), are time consuming while disrupting the cell or need excessive amounts of material (2); and sometimes it is difficult to release the cellular contents from mature hyphae or spores (19). Fungi with slow growth rates require growing cultures in liquid media in flasks or material that can be scraped from cellophane agar (17). Some protocols facilitate using new methodologies, with material such as 'reverse agar' (15), using standard DNA extraction protocols (8) or using fresh material (3). When spores are available suitable and quick methodologies have been developed for some species $(9,17)$. The aim of this study was to develop a simple, rapid and easy methodology for DNA template preparation that could be used for PCR genetic studies on this pathogen, that grows slowly, sporulates on solid media, and has melanized spores and mature mycelia.

The consistency of PCR markers in all methodologies tested was verified in monosporic culture of $C$. lindemuthianum, obtained from single conidia isolated using a micromanipulator on an optical microscope. Different strains were used including a genetically modified hygromycin resistant construct; strain $\mathrm{H} 2$ (7).

Once isolated, single conidia were transferred individually to plates containing M3S liquid medium (10) and kept in the dark and at room temperature $\left(19-20^{\circ} \mathrm{C}\right)$ until the colony formed a fine mycelium that was suitable for testing (approximately 3 days). Initially PCR reactions were performed with DNA that was

\footnotetext{
* Corresponding author. Mailing address: Departamento de Biologia. Universidade Federal de Lavras, Caixa Postal 37. 37200-000, Lavras, MG, Brasil. E-mail: 1cdavide@ufla.br.
} 
extracted and purified using traditional methods of 'mycelium maceration' in the presence of liquid nitrogen, extraction buffer and different methods of purification $(6,10,13)$.

A second approach was to perform PCR reactions using protoplasts that were obtained by treating the mycelium with the enzymes Novozyme ${ }^{\mathrm{TM}} 234$ (Interpex) or Glucanex ${ }^{\mathrm{TM}}$ (Novo Nordisk) or a mixture of Glucanase (Interpex) and Driselase (Interpex). The enzyme cocktail volume was twice as much as the volume of the filtered dried mycelium used for each digestion. To facilitate the isolation of protoplasts, combinations of different digestion times and temperatures were tested in SCE buffer (sorbitol 1M, sodium citrate $100 \mathrm{mM}$, EDTA $60 \mathrm{mM}$ ). The digestion times varied from 2 to 4 hours at intervals of 30 minutes with temperatures specified by the enzyme supplier. The enzyme concentration used was according to the product supplier. Afterwards, protoplasts were suspended in water, heated to $95^{\circ} \mathrm{C}$ for 1 minute, centrifuged and the supernatant was used as template.

A third approach was based on precipitation and DNA isolation using ethanol $95 \%$ ( 2 volumes) and 10\% sodium acetate $(3 \mathrm{M} \mathrm{pH}$ 5.2) in an ice bath. There followed a centrifugation step and the pellet was resuspended in ice-cold $70 \%$ ethanol. A further centrifugation step removed the last traces of ethanol and the pellet was air-dried. The DNA was dissolved in water (11) after protoplast production and incubation.

The fourth approach was collection, suspension and incubation of mycelial tips in reverse osmosis water (Millipore) for 3-5 minutes at high temperature $\left(91^{\circ} \mathrm{C}\right)$, followed by PCR. To perform the PCR reaction, the minimum possible amount of mycelium was taken using fine forceps (approximately $1 \mathrm{~mm}^{2}$ of mycelium).

Different DNA primers were employed in this study (Table 1) designed from sequences known and deposited in Genbank. They were based on sequences encoding ribosomal DNA (internal transcribed spacer: its), for recognising the pAN7.1 ( $h p h r$ or $h p h$ ) hygromycin plasmid, for the endopolygalacturonase gene of $C$. lindemuthianum ( $\mathrm{clpg}$ ) and for the glyceraldehyde-3-phosphate dehydrogenase gene of $C$. lindemuthianum (clgpd). The total reaction volume was $25 \mu \mathrm{l}$ containing 1.5 units Taq polymerase, $10 \mathrm{x}$ reaction buffer, $\mathrm{MgCl}_{2}$ at 25-50 mM, dNTPs at $10 \mathrm{mM}$, each primer at $10 \mathrm{pM}$ and a variable quantity of DNA template depending on the concentration of the DNA in the sample, i.e. $0.5 \mu 1$ of the plasmid was used compared to 2 to $4 \mu 1$ of mycelial supernatant.

The conditions for the PCR reaction were denaturation at $91^{\circ} \mathrm{C}$ for 30 seconds, annealing temperature (varied according to the primer used (Table 1) for 60 seconds; extension at $72^{\circ} \mathrm{C}$ for 70 seconds and repeated for 35 cycles. Finally, a last cycle of 10 minutes at $72^{\circ} \mathrm{C}$ was followed by holding at $4^{\circ} \mathrm{C}$. Amplification was carried out using a thermocycler of individual PCR minitubes (MJ Research Thermocycler - GRI). The PCR products were loaded into a $1.5-2.5 \%$ agarose gel, run at $100 \mathrm{~V}$ for 30-60 minutes, stained with ethidium bromide $(1 \mu \mathrm{g} / \mathrm{ml})$ and visualized on a UV trans-illuminator.

Amplification occurred for all methodologies deployed including the fourth approach, when the incubation period was restricted to less than four minutes (Fig. 1a-b). However, when DNA was extracted and stored in Millipore water and frozen at $-20^{\circ} \mathrm{C}$ for over one month, the amplification products were not comparable with those obtained earlier, indicating that using fresh material was the best strategy (Fig. 1c).

With protoplasts, no differences were found in the results for different enzymes. However, Glucanex is currently promptly available and less expensive than the others. SCE (pH3-4) buffer was used for Glucanex for 3 hours at $37^{\circ} \mathrm{C}$ at a concentration of $75 \mathrm{mg} / \mathrm{ml}$.

The rapid amplification of small segments of DNA $(<700 \mathrm{bp})$ was efficiently obtained using a small quantity of mycelium (the minimum possible) collected with a forceps and deposited directly in the minitube for PCR containing $5 \mu 1$ of Millipore

Table 1. DNA sequence of primers designed and used for PCR reactions.

\begin{tabular}{|c|c|c|c|c|}
\hline Primer & $\operatorname{Tm}\left({ }^{\circ} \mathrm{C}\right)$ & $5^{\prime}-3^{\prime}$ & Product (bp) & Reference \\
\hline its1 & 65 & CTT GGT CAT TTA GAG GAA GTA A & (its4) 600 & 18 \\
\hline its 4 & 58 & TCC TCC GCT TAT TGA TAT GC & (its 1) 600 & 18 \\
\hline its 5 & 63 & GGA AGT AGA AGT CGT AAC AAG G & (its2) 315 & 18 \\
\hline its6 & 62 & GAA GGT GAA GTC GTA ACA AGG & (its2) 315 & 5 \\
\hline$h p h 1$ & 53 & CAG CGA GAG CCT GAC CTA TTG C & $($ hph2) 711 & 12 \\
\hline hph2 & 63 & GCC ATC GGT CCA GAC GGC CCG CGC & $($ hph1) 711 & 12 \\
\hline hphrl & 73 & GCA GCC GGT CGC GGA GGC CAT GG & $($ hphr6) 450 & 12 \\
\hline hphr6 & $>75$ & CGC CCG GAG CCG CGG CGA TCC TGC & $(h p h r 1) 450$ & 12 \\
\hline $\operatorname{clpg} 1$ & 80 & CAA GGG CAC CAC CAC CTT TGG CTA C & $(C l p g 2) 300$ & 4 \\
\hline clpg2 & 74 & GCT CGA CGT TGA CAC TGG GAC GGT & (Clpg1) 300 & 4 \\
\hline clgpd1 & 78 & CAC GCG TTA TGG AACGAG CGC CTG C & $(C \lg p d 2) 500$ & gi $2209088 *$ \\
\hline $\operatorname{clgpd2}$ & 76 & GGT GGG GTG ATT AAG GCA AA & $(C \operatorname{Cgpd1}) 500$ & gi $2209088 *$ \\
\hline
\end{tabular}

* Original gene sequence in Genbank, accession number: AF000310; Direct submission by Dufresne, M \& Langin, T., 1997. 


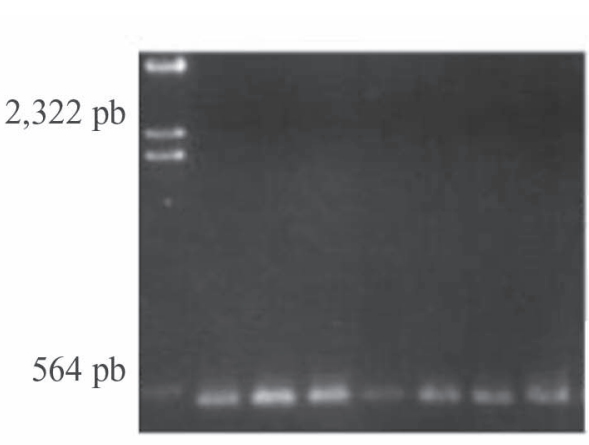

(a)

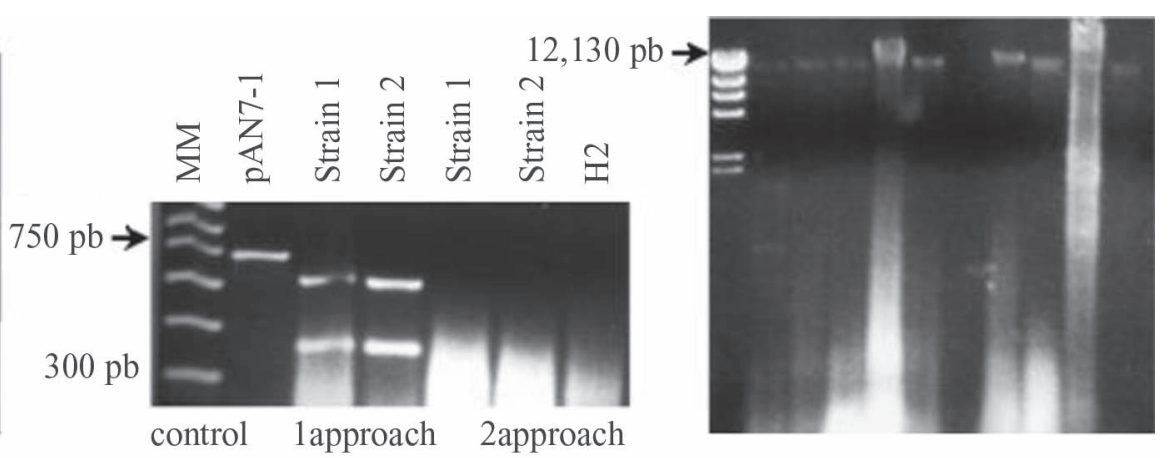

(b)

(c)

Figure 1. Different approaches for DNA extraction and PCR conditions: (a) Agarose gels (1.5\% w/v) with PCR products with annealing temperature of $58^{\circ} \mathrm{C}$; DNA from different strains; primer $c l g p d$; DNA isolated after 'nitrogen maceration of the mycelium' and DNA purification. Marker HindIII digest; (b) Agarose gels $(2.5 \%$ w/v) with PCR products with annealing temperature of $55^{\circ} \mathrm{C}$ and $12 \mu \mathrm{l}$ of reaction product on the gel (except, $5 \mu 1$ in sample 1 ). Samples: mm: Novagen ${ }^{\mathrm{TM}}$ marker, lane 2 : pAN7-1 product with $h p h 1$-hph2 (first approach); lanes 3 and 4: strains 01 and 02, isolated, purified and stored DNA at least for one month, primers clgpd1-clgpd2 (second approach); lanes 5and 6: strains 01 and 02, template from supernatant of Glucanex enzyme suspension, $95^{\circ} \mathrm{C}$ for 6 minutes, primers $\operatorname{clgpd1}$-clgpd2; lane 6: strain $\mathrm{H} 2$, the same methodology as before for DNA isolation, primers $h p h 1-h p h 2$; (c) Agarose gels $(1.5 \% \mathrm{w} / \mathrm{v})$ with DNA purified twice and stored for 1 month. First lane molecular marker HindIII digest. Other lanes: different strains.

water. Simultaneously the PCR reaction mixture was prepared and kept cold in another tube, waiting for the template. The minitube containing mycelium was put in the thermocycler at $91^{\circ} \mathrm{C}$ for 3 minutes, and then kept on ice. $4 \mu \mathrm{l}$ of the supernatant was collected without centrifugation and used as a template in a $20 \mu \mathrm{l}$ reaction mixture containing $\mathrm{MgCl}_{2} 1.25 \mathrm{mM}$.

The PCR reaction performed directly on the mycelium was an efficient methodology to amplify DNA sequences smaller than 700bp. This result was demonstrated when primers (see Table 1 for details) hphr1-hphr6 (Fig. 2a) and clpg1-clpg2 were used. A larger product than 700 bp was observed only on the reaction with pAN7-1 plasmid as template with the primer pair hph1-hph2 (Fig. 2b). However, the template copy number would have been much higher than from mycelial samples. In the case of primers its 1 -its 4 , its4-its5, its4-its 6 where the product size was bigger than $700 \mathrm{bp}$, amplification occurred only when previously isolated DNA or protoplasts were used (Fig. 3a). A long incubation period for cells is likely to have led to DNA breakage resulting in non-amplification of longer segments of DNA (Fig. 1b, lines 4-6). On the other hand, an incubation time that was too short would result in insufficient DNA being released into the reaction mix.

The annealing temperature used for most reactions was $55^{\circ} \mathrm{C}$. In some cases, where the specific annealing temperature indicated by the enzyme's supplier was used, amplification did not occur if a high temperature had been previously used for incubation. The lack of amplification, however, may be

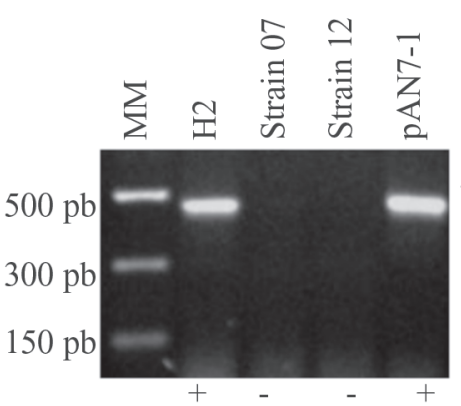

(a)

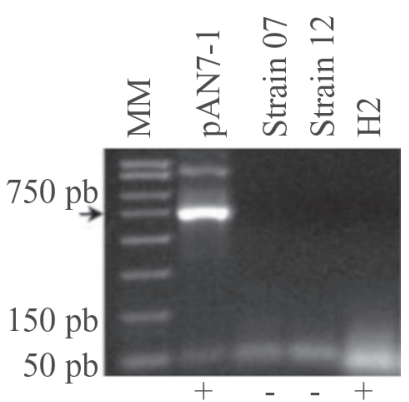

(b)
Figure 2. Agarose gels with PCR products produced directly from mycelium (fourth approach). Isolates H2 (positive control), pAN7-1 (positive control), 07 (negative control) and 12 (negative control). Annealing temperature $55^{\circ} \mathrm{C}$ : (a) Primers hprh1-hphr6. Agarose 2.5\%. (b) Primers $h p h 1$ - $h p h 2$. Agarose 1.5\% (w/v).

due to the presence of inhibitors in the reaction, which did not allow the correct primer-template binding. It is supported by the observation that when the primers clpg1-clpg2 for DNA isolated at temperatures of $58^{\circ} \mathrm{C}$ were used, amplification occurred normally (Fig. 3b). The quality of the template was such that increasing the annealing temperature gave sharper bands as the non-specific binding was reduced (Fig. 3b). When the annealing temperature below that indicated for each primer was used, the presence of different products was 

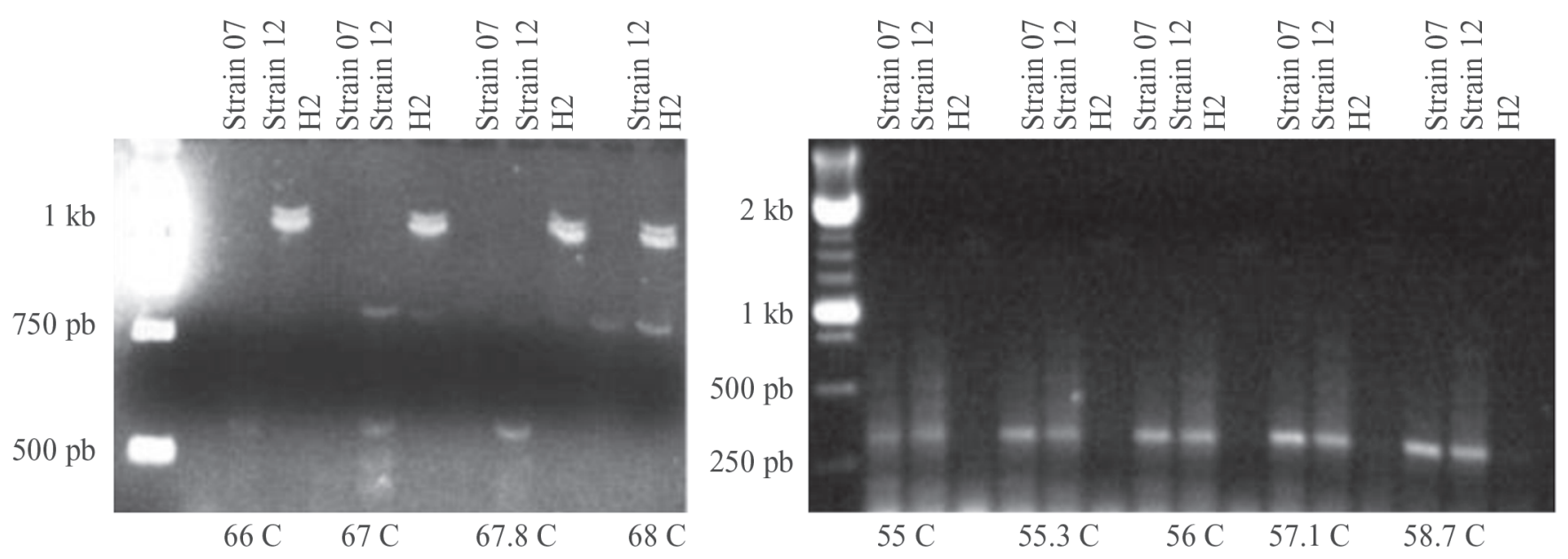

Figure 3. Agarose gel $(2.0 \% \mathrm{w} / \mathrm{v})$ with gradient PCR products: (a) The template was obtained after DNA precipitation and purification, with protoplast production at high temperature for 1 minute. Strains H2, 07 and 12. Primer pairs its5-its6; (b) the template was obtained after precipitation and purification of the water suspension of protoplasts at high incubation temperature. Strains H2, 07 and 12. Primer pair clpg1-clpg2. Lane one: Molecular marker - 250 bp ladder.

observed for some reactions, probably due to mis-priming (Fig. 1b, lanes 2-3).

With the hph1-hph2 primer pair at temperatures at or just above the Tm it is still possible to get specific annealing and good amplification if the template was of good quality and/or of high concentration. An example is with the plasmid where the relative concentration of template is high compared to the same target in the entire genome (Fig. 1b, Lane 1).

Using PCR methodology directly on mycelium is a rapid, practical and easy method that can be applied especially in the evaluation of a large number of samples and when the quantity of cells available is limited. However, the satisfactory results obtained here were only applicable to smaller amplicons. There is also variable intensity in PCR products that was expected because of the variable amount of DNA in the template. This methodology can be deployed successfully for genetic studies of other species but adaptations and/or modifications may be necessary because of cell wall composition, type of cell used.

Other methodologies have been developed such as PCR directly on spores without enzymes, using disruption by freezing and detergent (19), directly disrupting the spores (1), or by spore microwave treatment (9) and using enzymes for those products longer than $1 \mathrm{~kb}(20)$. Here we present a simple, rapid and easy method for PCR-DNA extraction on young mycelia, with which it is possible to obtain a template in less than ten minutes. This method will allow the evaluation of a large number of samples in a relative short time allowing large scale screening of molecular markers for genetic characterization of $C$. lindemuthianum.

\section{ACKNOWLEDGEMENT}

We thank CAPES-Brazil for a scholarship (MGRM), Robert Cragg (University of Bath, UK) for his collaboration with enzymatic assays with Driselase, Dr. Pedro Sanchez (University of Bath, UK) for useful discussions, comments on the methodology, for plasmid pAN7-1 and for primers $h p h 1-h p h 2$, and Dr. Bernard Dumas (Université de Toulouse, France) for the $\mathrm{H} 2$ isolate. CAPES and FAPEMIG (Brazil) financed this project.

\section{RESUMO}

\section{Preparação de DNA molde para PCR rápido em Colletotrichum lindemuthianum}

A extração de DNA para realização de PCR é demorada e envolve vários reagentes. O objetivo deste trabalho foi desenvolver uma metodologia rápida e fácil que permita utilizar a técnica de PCR sem necessidade de extração de DNA. Diferentes isolados de Colletotrichum lindemuthianum foram utilizados. Para obtenção do DNA moldes foram testados protoplastos obtidos através do uso de enzimas líticas, incubados sob altas temperaturas e diferentes metodologias. Uma metodologia rápida (10 minutos) foi desenvolvida para produtos de PCR menores $(<750 \mathrm{pb})$.

Palavras-chaves: antracnose, espaços transcritos internamente, metodolologias de PCR, resistência a higromicina, triagens rápidas. 


\section{REFERENCES}

1. Aufauvre-Brown, A.; Tang, C.; Holden, D. Detection of genedisruption in Aspergillus transformants by polymerase chain reaction direct from conidiospores. Curr. Genet., 24: 177-178, 1993.

2. Burt, A.; Carter, D.; Koenig, G.; White, T.; Taylor, J. A safe method of extracting DNA from Coccidioides immitis. Fungal Genet. Newsl., 42: 23, 1995.

3. Cenis, J.L. Rapid extraction of fungal DNA for PCR amplification. Nucl. Acids Res., 20: 2380, 1992.

4. Centis, S.; Guillas, I.; Séjalon, N.; Esquerré-Tugayé, M-T. Endopolygalacturonase genes from Colletotrichum lindemuthianum: cloning of CLPG2 and comparison of its expression to that of CLPG1 during saprophytic and parasitic growth of the fungus. Molec. plant-microbe interac., 10: 769-775, 1997.

5. Cooke, D.; Duncan, J. Phylogenetic analysis of Phytophthora species based on ITS1 and ITS2 sequences of the ribosomal RNA gene repeat. Mycolog. Res., 101: 667-677, 1997.

6. Duarte, J.M.; Santos, J.B.; Melo, L. Comparison of similarity coefficients based on RAPD markers in the common bean. Genet. Molec. Biol., 22: 427-432, 1999.

7. Dumas, B.; Centis, S.; Sarrazin, N.; Esquerré-Tugayé, M-T. Use of green fluorescent protein to detect expression of an endopolygalacturonase gene of Colletotrichum lindemuthianum during bean infection. Applied environm. microbial., 65: 1769-1771, 1999.

8. Edwards, K.; Johnstone, C.; Thompson, C. A simple and rapid method for the preparation of plant genomic DNA for PCR analysis. Nucl. Acids Res., 19: 1349, 1991.

9. Ferreira, A.; Glass, N.L. PCR from fungal spores after microwave treatment. Fungal Genet. Newsl., 43: 25-26, 1996.

10. Gonzáles, M.; Rodriguez, R.C; Zavala, M.E.; Jacobo, J.L.; Hernández, F.; Acosta, J.; Martínez, O.; Simpsom, J. Characterization of Mexican isolates of Colletotrichum lindemuthianum by using differential cultivars and molecular markers. Phytopathology., 88: 292-299, 1998.

11. Maniatis, T.; Fritsch, E.F.; Sambrook, J. Molecular cloning: a laboratory manual. N. York, Cold Spring Harbour laboratory. 1982. $545 \mathrm{p}$.

12. Punt, P.J.; Oliver, R.P.; Dingemanse, M.A.; Pouwels, P.H.; Van Den Hondel, C.A.M.J.J. Transformation of Aspergillus based on the hygromycin B resistance marker from Escherichia coli. Gene., 56: 117-124, 1987.

13. Raeder, U.; Broda, P. Rapid preparation of DNA from filamentous fungi. Lett. Appl. Microbiol., 1: 17-20, 1985.

14. Rava, A.C.; Sartorato, A. Antracnose. In: Rava, A.C.; Sartorato, A. (eds.) Principais doenças do feijoeiro comum e seu controle. Brasília, Empresa brasileira de pesquisa agropecuária, 1994, p. 17-40.

15. Seifert, K. A novel method of growing fungi for DNA extraction. Fungal Genet. Newsl., 41: 79-80, 1994.

16. Tu, J.C. An improved Mathur's medium for growth, sporulation and germination of spores of Colletotrichum lindemuthianum. Microbios., 44: 87-93, 1985.

17. Wendland, J.A.; Lengeler, K.B.; Kothe, E. An instant preparation method for nucleic acids research. Fungal Genet. Newsl., 43: 54-55, 1996.

18. White, T.J.; Bruns, T.; Lee, S.; Tailor, J. Amplification and direct sequencing of fungal ribosomal RNA genes for phylogenetics. In: Innis, N.; Gelfand, D.; Skinsky, J.; White, T. (eds.). PCR products: a guide to methods and applications. N. York, Academic Press, Inc. 1990, p. 315-322.

19. Xu, J.R.; Hamer, J.E. Assessment of Magnaporthe grisea mating type by spore PCR. Fungal Genet. Newsl., 42: 80, 1995.

20. Zeijl Van, C.M.J.; Kamp Van, E.H.M.; Punt, P.J.; Selten, G.C.M.; Hauer, B.; Gorcom Van, R.F.M.; Hondel Van Den, C.A.M.J.J. An improved colony-PCR method for filamentous fungi for amplification of PCR-fragments of several kilobases. J. Biotechnol., 59: 221-224, 1998. 